| Metode Terapi dan Rehabilitasi Korban Napza

\title{
METODE TERAPI DAN REHABILITASI KORBAN NAPZA DI PONDOK PESANTREN SURYALAYA TASIKMALAYA
}

\author{
Oleh: Puji Lestari ${ }^{1}$
}

\begin{abstract}
Abstrak
Penelitian ini bertujuan untuk mengetahui secara mendalam metode pembinaan dan penyadaran korban penyalahgunaan NAPZA (Narkotika, Psikotoprika, dan Zat Adiktif lainnya) di Pondok Pesantren Suryalaya Tasikmalaya Jawa Barat.

Metode yang digunakan dalam penelitian ini adalah penelitian kualitatif deskriptif. Dengan penelitian ini diharapkan dapat mengungkap berbagai informasi kualitatif dengan deskripsi-analisis yang teliti dan penuh makna. Pada tiap-tiap obyek akan dilihat kecenderungan, pola pikir, ketidakteraturan, serta tampilan perilaku dan integrasinya sebagaimana dalam studi kasus genetik. Strategi yang digunakan dalam penelitian ini adalah studi kasus (case study).

Hasil penelitian menunjukkan bahwa pembinaan dan penyadaran korban penyalahgunaan NAPZA melalui metode Zikrullah. Zikrullah dimaksudkan sebagai alat penenang hati, penyembuhan segala penyakit hati, pembersih hati, dan sebagai alat peningkatan iman kepada Allah. Adapun materi rehabilitasi meliputi mandi malam atau mandi taubat, shalat-shalat wajib dan sunah, zikir, membaca Alqur'an, riyadlah, pengajian rutun mingguan dan bulanan, do'a-do'a, dan pembelajaran tentang keilmuan seperti Fiqh, Tauhid, Akhlak, dan Tashawuf.
\end{abstract}

Kata Kunci: PP Suryalaya, Inabah, Rehabilitasi, NAPZA

\footnotetext{
${ }^{1}$ Dosen Pendidikan Sosiologi Fakultas IImu Sosial Universitas Negeri Yogyakarta
} 


\section{A. Pendahuluan}

Pada zaman yang serba kompleks dan tuntutan hidup semakin tinggi, maka permasalahan bangsa semakin kompleks juga. Berbagai krisis melanda bangsa ini, mulai dari krisis keteladanan, krisis moral, budaya, politik, hingga pada krisis ekonomi yang melanda tiada henti. Berbagai penyakit sosial melanda di mana-mana, menggerogoti bangunan bangsa ini hingga diambang kehancuran. Di satu sisi mental generasi tua yang sulit diubah, terlena dengan kesenangan yang sifatnya duniawi sehingga praktek-praktek korupsi terjadi di hampir segala bidang, dan deviasi-deviasi sosial yang lain, sementara generasi muda juga sama berada diujung tanduk, terlibat berbagai tawuran, NAPZA (Narkotika, Psikotropika, dan Obat berbahaya lainnya), pelacuran, dan penyimpangan-penyimpangan lain baik yang bersifat primer maupun sekunder.

Eksistensi generasi muda betul-betul sedang mendapatkan ujian yang berat, dan memerlukan penanganan yang segera dari berbagai pihak terutama pemerintah. Jika hal tersebut tidak segera ditangani, maka generasi muda ke depan tidak akan memiliki arah dan tujuan yang jelas, dan bahkan kehilangan masa depan yang gemilang. Penyimpangan sosial yang dilakukan oleh para remaja, memang merupakan suatu problem yang senantiasa selalu muncul di tengah-tengah masyarakat yang serba dinamis. Problema tersebut tumbuh, berkembang, dan merasuk di segala sendi-sendi kehidupan, dan membawa akibat-akibat yang destruktif dan kronis, sulit untuk diurai benang merahnya, sebab pada dasarnya para remaja tersebut telah jauh melakukan deviasi sosial dalam bentuk-bentuk yang kompleks, telah merusak nilai-nilai susila, nilai-nilai luhur agama, dan bahkan merusak nilai-nilai hukum.

$$
\text { Pada akhir-akhir ini, }
$$

kenakalan remaja yang paling berpotensi membunuh masa depan bangsa terutama kelangsungan hidup wajar dan berbudaya adalah penyalahgunaan napza. Bahkan di banyak negara baik negara-negara maju maupun negara berkembang, masalah penyalahgunaan napza merupakan masalah krusial yang memerlukan penanganan khusus melalui berbagai metodologi dan strategi. Terlebih di Indonesia, pada saat degradasi moral yang terus menurun, kecenderungan angka penyalahgunaan napza semakin meningkat. Fenomena ini terjadi tidak saja melanda mereka yang berasal dari kalangan menengah ke atas, melainkan juga pada masyarakat kelas menengah ke bawah.

Gejala-gejala sosial dan bahaya yang ditimbulkan oleh masalah penyalahgunaan napza dewasa ini bukan saja masalah sosial, melainkan pula menjadi masalah nasional yang akut. Hampir $\quad 90 \quad \% \quad$ korban penyalahgunaan napza di Indonesia adalah remaja, dan di samping mereka sebagai pemakai, juga sebagai pengedar yang berpotensi lebih besar menghancurkan bangunan bangsa ini. Hasil 
penelitian pemerintah pada tahun 1995 menyebutkan bahwa korban penyalahgunaan napza adalah 0,065\% dari 200 juta penduduk atau sekitar 130.000 orang. Angka tersebut jauh berbeda dari hasil penelitian Hawari dan kawankawan yang dilakukan pada 1998. Menurut penelitian tersebut, korban napza sekitar 10 kali lipat temuan pemerintah. Seandainya asumsi penelitian pemerintah benar, korban napza di Indonesia (1998) 10 kali 130.000 orang atau berjumlah 1.300.000 orang. Pada 2006 ini, diperkirakan tidak kurang 3.000.000 orang terlibat dalam penyalahgunaan napza.

Dengan

semakin kompleksnya masalah kenakalan remaja dalam penyalahgunaan napza, mendorong berbagai pihak untuk terlibat dalam proses penanganan masalah sosial-nasional tersebut. Di samping pemerintah, banyak pula pihak-pihak nonpemerintah yang ikut berkecimpung dalam proses penanganan masalah penyalahgunaan napza tersebut. Berbagai metode dan strategi ditawarkan baik yang sifatnya preventif, kuratif, maupun rehabilitatif. Secara preventif, telah banyak diupayakan melalui seminar-seminar, lokakarya, diskusi ilmiah dan berbagai kegiatan sejenisnya yang menghadirkan pembicara dari berbagai kalangan ahli yang memberikan dan menawarkan berbagai solusi baik dalam mencegah, mengobati, dan merehabilitasi para remaja korban napza. Sedangkan secara kuratif pemerintah melalui peran rumah sakit berperan dalam pengobatan medis korban ketergantungan napza. Namun demikian, dari upaya-upaya yang sedang dilakukan baik sifatnya preventif, kuratif, maupun rehabilitatif, belum menunjukkan hasil yang memuaskan.

Dalam pada itu, Pondok Pesantren (PP) Suryalaya Tasikmalaya Jawa Barat menawarkan solusi rehabilitasi korban napza secara terpadu, dengan prestasi yang cukup mencengangkan. Rehabilitasi terpadu tersebut memerlukan peran aktif pemerintah, keluarga, dan masyarakat. PP Suryalaya meyakini bahwa korban napza memerlukan sentuhan kejiwaan yang islami, dalam rangka proses penyadaran kembali ke jalan Allah. Melalui pendekatan Islami dengan penerapan ilmu Tasawuf Islam yang dikenal Tharekat Qodiriyah Naqsobandiyah. Dengan demikian, adalah menarik untuk mengkaji eksistensi PP Suryalaya terutama keterlibatannya dalam proses rehabilitasi korban napza, terutama menyangkut strategi, metode, dan teknik penyadaran serta pembinaan korban napza tersebut. Berdasarkan gambaran permasalahan pada latar belakang masalah di atas, maka permasalahan yang akan dikaji dalam penelitian ini adalah bagaimana strategi, metode, dan teknik penyadaran dan pembinaan korban napza yang dijalankan oleh 
PP Suryalaya Tasikmalaya Jawa Barat.

\section{B. Konsep Napza}

NAPZA

(Narkotika,

Psikotropika, dan Zat Aditif lainnya), merupakan zat atau obatobatan yang berpengaruh terhadap susunan syaraf atau otak. Berdasarkan UU RI No.22 tahun 1997, zat yang digolongkan ke dalam jenis narkotika adalah opiad (opium, morfin, heroin, codein, pethidin); kanabis (ganja, marihuana, hasish); dan kokain serta daun koka. Berdasarkan UURI No.5. tahun 1997, zat yang dapat digolongkan ke dalam jenis psikotropika adalah berupa obat penenang (bromazepam dan nipam); obat tidur seperti dumolit; zat halusinogenik (meskalin, psilosin, psilosibin); serta zat psikotimulansia (ampetamin, inex, shabu-shabu). Sedangkan zat yang bersifat adiktif selain yang termasuk narkotika dan psikotropika adalah minuman keras yang mengandung alkohol, sloven, nikotin, dan kafein.

Adapun jenis-jenis narkotika dan psikotropika yang akhir-akhir ini sering dikonsumsi atau disalahgunakan oleh kalangan muda adalah ganja (cimeng, gele, grash, rumput, marihuana); heroin berupa putaw dan pe te; serta anfetamin seperti inex dan shabushabu. Sedangkan konsep penyalahgunaan napza pemakaian di luar indikasi medis tanpa petunjuk atau resep dokter. Sementara ketagihan atau addiction adalah pemakaian napza secara relatif teratur atau berkala, bersifat patologik atau merusak, dan menimbulkan hendaya atau ketidakmampuan dalam fungsi sosial, pekerjaan, dan sekolah (Anang Syah, 2000).

$$
\text { Setiap orang yang }
$$

menyalahgunakan napza, pada umumnya karena rasa keingintahuan dan keinginan untuk mencoba, apakah karena pengaruh pergaulan, pemaksaan, atau kehendak sendiri untuk merasakannya. Pada gilirannya menjadi kebiasaan dan meneruskannya, karena berbagai alasan seperti menyukai efek yang terjadi pada dirinya (reactional use); menjadikannya untuk mengatasi stress atau prustasi (recreational use); sebagai pernyataan diri hebat atau sudah dewasa (anticipatory beleife); dan perubahan nilai kehidupan yang menganggap bahwa menggunakan napza sebagai suatu prestise dan gaya hidup modern (facilitative beleife).

\section{Dampak Napza}

Ketergantungan

napza

merupakan penyalahgunaan napza disertai dengan adanya toleransi dan gejala putus (withadral symtom). Toleransi di sini berarti bahwa berkecenderungan untuk menambah takaran atau dosis zat sesuai dengan kebutuhan tubuh karena efek dan zat tersebut tidak dirasakan lagi oleh tubuh. Akibat yang ditimbulkan sangat kompleks karena napza telah merusak kecakapan sosial, kepribadian, pola pikir yang ingin serba cepat, longgarnya norma, dan gangguan fisik seperti tubuh semaik kering, suka gemetaran, dan tidur siang 
sementara malam hari begadang. Penderita sudah tidak lagi memiliki nilai-nilai moral dan kecakapan sosial sebagaimana layaknya orangorang normal.

Sementara dampak pada fisik tampak sangat jelas seperti tubuh menjadi kurus; muka pucat, merah, layu, cekung, bibir hitam pucat; tangan dan lengan bekas tusukan jarus seperti gigitan nyamuk, bengkak dan merah; bicara cadel (slurred speech); keadaan kurang terurus, kumal dan dekil; serta susah buang air besar dan kecil. Sementara itu keadaan emosi sangat sensitif seperti mudah marah dan sedih; mudah tersinggung; merasa resah dan cemas; perasaan tidak menentu kadang riang kadang murung; merasa rendah diri dan tidak punya keyakinan diri; cepat curiga, merasa malu dan mudah kecewa; serta apabila berjanji mudanh ingkar. Dampak lain yang sangat destruktif adalah pada perubahan pola pikir yang tidak normatif, tidak sempurna dan tidak logis; perilaku yang tidak wajar; keadaan sosial yang tidak lagi dengan kecakapan; serta kebiasaankebiasaan lain yang jelek seperti mengusap muka, menggaruk-garuk kepala, merokok tidak putus-putus, tidur sewaktu duduk, dan lain sebagainya.

Dalam pada itu, kekeliruan
dan kesalahfahaman tentang pemakaian nafza dapat ditunjukkan dengan keyakinannya seperti dalam hal: merangsang kreativitas (pencipta lagu, artis), menjadi sebuah mitos karena belum ada penelitian tentang itu; dianggap menyelesaikan masalah yang pada kenyataannya justru semakin memperkompleks masalah; dianggap dapat meningkatkan percaya diri yang pada awalnya dirasakan demikian tetapi lama kelamaan malah semakin minder karena masalah ketergantungannya; dianggap dapat meningkatkan gairah seksual padahal malah justru sebaliknya; dan merasa bisa menyembuhkan diri sendiri sendiri tanpa bantuan orang lain, padahal pada hakikatnya pemakai tidak dapat mengontrol dirinya sehingga sulit untuk mendisiplinkan diri.

\section{Qadiriyah Naqsabandiyah}

Tareqat adalah Sebuah Metode atau cara atau jalan lurus untuk menuju kepada Allah, dengan bimbingan seorang guru spiritual atau Mursyid. Tarekat Qadiriyah Naqsyabandiyah adalah dua metode yang digabungkan (unity) sehingga menjadi satu kesatuan. Adapun pengamalan Tareqat adalah bukan berkiblat pada suatu aliran tertentu tetapi melengkapi ibadah kita dengan Metode Dzikir yang bersifat Khos dan Khasanah bersifat khusus dan baik dengan metode dzikrullah "Laa Illa Ha Illallah". Ajaran Qadiriyah didirikan oleh Syekh Abdul Qadir Al-Jaelani dari Jilan Irak dan kedua adalah Tareqat Naqsyabandiyah didirikan oleh syekh Bahauddin Naqsyaband dari Bukhara. Sementara Thareqat Qadiriyah dan Naqsyabandiyah didirikan oleh Syekh Syamsuddin di Mekkah, dan 
dikembangkan di Indonesia oleh Syekh Ahmad Khatib seorang ulama asal Indonesia yang bermukim di Mekkah hingga wafatnya.

Di Indonesia, ajaran Tarekat Qodiriyah-Naqsyabandiyah ini lalu di bawa oleh tiga orang murid Syekh Ahmad Khatib yang sempat bertemu di Mekkah. Mereka masing-masing adalah Syekh Tolhah, Kalisapu, Al-Cireboni, Syekh Abdul Karim al-Bantani, dan Syekh Al-Hasbu Al-Maduri. Namun dari ketiga murid Syekh Ahmad Khatib Al-Sambasi, hanya satu yang ajaran Tarekatnya hingga kini berkembang, yakni Syekh Tolhah Kalisapu. Tapi pengembangan yang lebih luas dari ajaran Tarekat Qodiriyah Naqsyabandiyah ini, terutama sekali dilakukan oleh murid Syekh Tolhah bernama Syekh Abdullah Mubarok bin Nur Muhammad (Abah Sepuh). Setelah wafat, ajaran Tarekat Qadiriyah Naqsyabandiyah kemudian diteruskan oleh putranya yang bernama Syekh Ahmad Shohibul Wafa Tajul Arifin alias Abah Anom. Dari Abah Anom inilah, ajaran Tarekat Qadiriyah Naqsyabandiyah lalu dikembangkan oleh para muridnya yang telah diberi otoritas khusus (khirqah) untuk mengajarkan dzikir. Dalam tradisi Tarekat Qadiriyah Naqsyabandiyah, baik pada masa Abah Sepuh dulu maupun Abah Anom sekarang, otoritas khusus itu biasa disebut dengan Wakil Talqin.

Secara khusus, aktivitas ajaran Tarekat Qadiriyah Naqsyabandiyah saat ini dikembangkan dan dipusatkan di
Pondok Pesantren Suryalaya, Tasikmalaya, Jawa Barat dengan cabang-cabangnya yang tersebar di seluruh Tanah Air dan beberapa negara di Asia Tenggara, seperti Singapura, Brunai Darussalam, dan Malaysia. Dari pesantren ini pula lalu berkembang sebuah lembaga yang secara khusus menangani para penderita ketergantungan obat (narkoba), atau yang lebih popular disebut Pondok Inabah. Dengan menggunakan metode dzikirullah yang diambil dari wirid dan dzikir Tarekat Qadiriyah Naqsyabandiyah sebagai alternatif pengobatannya, jumlah lembaga Inabah kini mencapai kurang lebih 25 buah. Tersebar bukan hanya di Jawa Barat, tapi juga di DI Yogyakarta dan Asia Tenggara. Sanggar Meditasi \& Tanaman Obat yang di Asuh oleh Rizki Joko Sukmono, SH yang pernah belajar Ilmu Tashawuf di Pon Pes Suryalaya Tasikmalaya Jawa Barat, juga mengembangkan dan mempopulerkan di kalangan murid-muridnya di kota Jember Jawa Timur dengan maksud bukan menthareqatkan orang lain tetapi dalam rangka membina mental dan spiritual serta aqidah pada muridmuridnya khususnya yang beragama Islam itupun tanpa paksaan bagi mereka yang berkenan untuk bergabung pada Majelis Dzikirnya yang terkenal dengan Majelis Dzikir "adem ati" yang mengamalkan ajaran guru Mursyid TQN dari Mursyid Abah Anom. Zikrullah dimaksudkan sebagai alat penenang hati, penyembuhan segala penyakit hati, pembersih hati, dan sebagai alat peningkatan iman kepada Allah (Zaenal Abidin A, 
| Metode Terapi dan Rehabilitasi Korban Napza

2006: 2).

\section{E. Metode Penelitian}

Metodologi merupakan konsep teoritik yang membahas mengenai berbagai metode atau ilmu metode-metode, yang dipakai dalam penelitian. Sedangkan metode merupakan bagian dari metodologi, yang diinterpretasikan sebagai teknik dan cara dalam penelitian, misalnya teknik observasi, metode pengumpulan sumber (heuristik), teknik wawancara, analisis isi, dan lain sebagainya. Berdasarkan permasalahan yang diajukan dalam penelitian ini, yang lebih mengutamakan pada masalah proses dan makna/persepsi, maka jenis penelitian dengan strateginya yang cocok dan relevan adalah penelitian kualitatif deskriptif. Dengan penelitian ini diharapkan dapat mengungkap berbagai informasi kualitatif dengan deskripsi-analisis yang teliti dan penuh makna. Pada tiap-tiap obyek akan dilihat kecenderungan, pola pikir, ketidakteraturan, serta tampilan perilaku dan integrasinya sebagaimana dalam studi kasus genetik. Strategi yang digunakan dalam penelitian ini adalah studi kasus (case study).

\section{F. Hasil Penelitian \\ 1. Konsep Umum}

Pada awalnya, napza (narkotik, psikotoprika, dan zat adiktif) berkembang di Inggris, negara-negara Eropa, Amerika, dan kemudian merebak ke Indonesia pada pada sekitar tahun 1969. Namun demikian, sebenarnya Indonesia sudah mengenal napza sejak zaman kolonial Belanda. Mereka yang mengkonsumsi napza akan mengalami perubahan mental dan perilaku dalam kehidupan sehari-hari. Hal itu disebabkan oleh terganggunya sistem transmisi saraf pada susunan saraf pusat atau otak dan mengakibatkan gangguan pada fungsi pikir, perasaan, dan perilaku (Dadang Hawari, 1998).

Perubahan perilaku yang kelihatan mencolok, antara lain meninggalkan ibadah, suka berbohong, membolos sekolah, suka mencuri, dan seks bebas. Selain itu juga akibat-akibat negatif lain, seperti malas, suka melawan, dan merusak barang. Pada awalnya kirakira sekitar tahun 1969, napza hanya dikonsumsi oleh kalangan keluarga elite. Namun, sekarang anak-anak dari keluarga menengah ke bawah sudah terjangkit pula oleh peredaran napza tersebut, sehingga menambah kompleks permasalahan, tidak saja masalah sosial-lokal, melainkan pula masalah nasional yang memerlukan penanganan khusus dari berbagai kalangan masyarakat.

Dapat dibayangkan tatkala anak keluarga miskin menjadi korban barang setan itu, padahal harganya sangat mahal. Dari mana mereka memperoleh uang untuk membelinya kalau tidak melakukan tindak kriminal, seperti mencuri, menodong, merampok, lalu yang wanita menjual diri dan sebagainya. Dampaknya, napza telah membuat 
generasi muda kehilangan masa depan mereka, mengingat penyalahgunaan napza memiliki dampak yang destruktif baik bagi dirinya maupun lingkungannya. Oleh karena itu sangatlah wajar manakala muncul fakta baru bahwa napza menimbulkan segudang masalah, baik masalah pelacuran, kriminal, dan bahkan paling berpotensi menularkan penyakit HIV Aids yang akhir-akhir ini sangat merebak dalam masyarakat Indonesia.

\section{Pondok Pesantren Suryalaya} PP Suryalaya, didirikan pada tahun 1905 oleh Syekh Abdullah Mubarok, dengan nama sebelumnya adalah PP Godebag, yang kemudian namanya diubah menjadi PP Suryalaya atas saran Syekh Tolhah. Pada 1972, mulai mengembangkan program bagi anak-anak atau orang tua korban ketergantungan naza. Para korban tidak dicampur dengan santri umum, tapi disediakan tempat khusus yang terpisah jauh. Tempat pembinaan mereka diberi nama Pondok Inabah. Pondok Inabah pertama ini berlokasi di Desa Cibeureum, Kecamatan Panjalu, Kabupaten Ciamis Jawa Barat. Kemudian secara resmi, PP Inabah mulai dilembagakan pada tahun 1980 dengan nama Pondok Remaja Inabah I atas prakarsa pimpinan atau sesepuh PP Suryalaya KH. Ahmad Shohibulwafa Tajul Arifin (Abah Anom), dengan tujuan untuk ikut berpartisipasi membina ahlaq dan mental para remaja korban penyalahgunaan napza untuk kembali kepada jalan Allah, melalui pendekatan Ilaahiyah dengan metode ilmu Tasawuf Islam Thareqat Qadiriyah Naqsabandiyah. PP Inabah I memiliki luas tanah kurang lebih 2 hektar dengan fasilitas di dalamnya terdiri dari mesjid, asrama, perumahan pembina, lapangan olah raga, dan fasilitas lainnya. Situasi asrama didesain sedemikian rupa sehingga menjadi kesatuan yang utuh baik itu antara pembina, anak bina, dan keluarga pembina. Dalam kegiatan yang menyangkut pelaksanaan ibadah, mandi, makan, olah raga, dan kegiatan lainnya dilakukan bersama dan diawasi oleh pembina. Hal tersebut dimaksudkan untuk lebih mendekatkan diri dan menumbuhkan kembali moral anak bina, yang tadinya berkehidupan bebas, dan kurang terkoordinasi. Dengan cara demikian, mereka merasa hidup secara teratur dan kembali menemukan kasih sayang dan perhatian. Pondok Inabah menerapkan metode dzikirullah yang diambil dari wirid dan dzikir Tarekat Qadiriyah Naqsyabandiyah sebagai alternatif pengobatannya. Sekarang ini jumlah lembaga Inabah mencapai kurang lebih 25 buah Pondok Inabah. Tersebar bukan hanya di Jawa Barat, tapi juga di DI Yogyakarta dan Asia Tenggara.

\section{Konsep Inabah}

Konsep Inabah merupakan istilah yang berasal dari bahasa Arab yakni anaba, yanibu, yang artinya adalah kembali. Istilah ini digunakan pula dalam Al-Quran yakni dalam Surat Luqman (31 ayat ke-15; Surat Al-Syura (42 ayat ke10). Dalam literatur kajian ilmu 
Tasawuf Islam dikenal pula istilah Inabah yang berarti kembali kepada Allah. Maksudnya adalah mengembalikan orang dari perilaku yang selalu menentang kehendak Allah atau maksiat, kepada perilaku yang sesuai dengan kehendak Allah atau berperilaku ta'at. Istilah ini dikembangkan oleh Abah Anom sebagai konsep perawatan korban penyalahgunaan korban napza, serta konsep perawatan remaja yang nakal dalam berbagai bentuk penyakit kerohanian.

Inabah sebagai suatu metode , baik secara teoritis maupun praktis berlandaskan pada Al-Qu'ran, hadits, dan ijtihad para ulama. Para korban Napza yang berhubungkait dengan kenakalan remana serta berbagai bentuk penyakit kerohanian dianggap sebagai orang yang berdosa karena melakukan maksiat. Dalam Islam, orang berdosa harus segera bertaubat meminta ampunan kepada Allah. Taubat secara etimologi berarti kembali dari dosa kepada ketaatan kepada perintah Allah dan RasulNya. Sedangkan dalam terminologi Islam, taubat adalah meninggalkan kejelekan disertai rasa penyesalan karena melakukannya serta dibarengi dengan tujuan kuat untuk meninggalkan selamanya. Dalam dunia Tasawuf, taubat berarti menyesali apa yang telah berlalu dan berkelanggengan melakukan segala yang suci. Taubat sebagai proses awal perawatan anak bina di Inabah yang dasar teoritisnya diambil dari Al-Qur'an, hadist, dan ijtihad.

\section{Metode Pembinaan}

Filosofi dasar yang melandasi terapi ketergantungan napza ialah ayat: dan Aku tidak menciptakan jin Dan manusia melainkan supaya mereka menyembah-Ku (Quran, Surat AdzDzaariyaat ayat 56). Jadi, pada hakikatnya tugas dan tanggung jawab manusia ialah mendekatkan diri kepada Allah, dengan manifestasi melaksanakan ibadah, seperti salat dan dzikir. Pada kasus ketergantungan napza, pada hakikatnya mereka adalah orangorang yang sedang mabuk. Terhadap orang yang mabuk terkena ayat, Hai orang-orang yang beriman, janganlah kamu salat, sedang kamu dalam keadaan mabuk, sehingga kamu mengerti apa yang kamu ucapkan. Jangan pula kamu hampiri masjid, sedang kamu dalam keadaan junub, terkecuali sekadar berlalu, hingga kamu mandi. (Q Surat An Nisaa ayat: 43). Pengertian dan kriteria mabuk menurut ayat tersebut adalah orang yang tidak menyadari dan tidak mengerti apa yang dia ucapkan.

Faktor penyebab mabuk adalah segala sesuatu yang dapat menyebabkan hilang kesadaran berpikir dan berucap, baik dengan cara dimakan, diminum, diisap, maupun disuntikkan. Bahkan, pemimpin Pesantren Suryalaya KH Zaenal Abidin Anwar memperluas pemahaman mabuk, antara lain mabuk harta, mabuk kekuasaan, mabuk pangkat, juga mabuk cinta. Untuk menangani kasus penyalahgunaan napza, terdapat tiga terapi yang dilakukan di 
Pondok Inabah. Pertama, mandi (mandi taubat), kedua sahlat, ketiga dzikir. Ketiga hal itu dilakukan setiap hari oleh penderita ketergantungan napza.

Pada tahap awal pembinaan, dimana anak bina diserahkan oleh orang tuanya untuk dibina dan disadarkan, terlebih dahulu pembina mewawancarai orang tua maupun anak bina. Korespondensi tersebut dimaksudkan untuk mengetahui sejauhmana tingkat keterlibatannya dalam penyalahgunaan napza, ketergantungannya, dan jenis napza yang dipakai. Selanjutnya adalah memandikan anak bina dengan istilah "mandi taubat" yang tujuannya adalah memberikan sugesti untuk bertaubat dan menurunkan kadar dari ketergantungannya. Di samping itu, apabila kadar ketergantungannya masih tinggi, anak bina diberi minum air asam dicampur gula merah, dan air kepala muda atau duwegan. Ini dimaksudkan untuk menurunkan radiasi napza yang ada dalam tubuhnya dan mengurangi ketergantungannya, sehingga diharapkan racun-racun dalam tubuhnya akan keluar (Wawancara KH.Zaenal Abindin, 26 Nopember 2006). Setelah mandi taubat, pagi harinya anak bina dibawa menghadap Abah Anom untuk menyadap Ilmu Tasawuf Islam melalui Talqin Dzikir yakni Dzikir jahar dan khofi. Selanjutnya setelah di talqin dzikir anak bina tersebut dibawa kembali ke Pondok Inabah untuk mengikuti proses pembinaan sesuai dengan kurikulum yang telah diprogrmakan.

Pada umumnya, korban penyalahgunaan napza dapat dikategorikan dalam dua bagian yaitu sebagai berikut.

a. Kategori pertama adalah yang disebut korban Dua Dimensi, dimana anak tersebut sebagai peminum minuman keras, pemakai pil atau obat, dan penghisap ganja. Efeknya adalah kelakuan anak tersebut $99 \%$ berbicara bohong, munafik, minat belajar tidak ada, dan lebih jauh lagi barang orang lain dianggap miliknya.

b. Kategori kedua disebut korban Lima Dimensi, dimana anak tersebut disamping menggunakan minuman keras, pil/obat dan menghisap ganja, juga menggunakan morfin, heroin, termasuk di dalamnya putaw dan sabusabu, kokain, serta masroom atau jamur kotoran babi dan sapi. Efeknya yaitu di samping efek kategori pertama serta kelakuan anak tersebut segala cara dapat dihalalkan, tingkat kesadaran sudah hilang atau lepas kontrol.

Sedangkan mengenai lamanya pelaksanaan pembinaan disesuaikan dengan tingkat ketergantungannya. Untuk kategori pertama atau Dua Dimensi lamanya pembinaan antara 40-90 hari. Sedangkan untuk kategori kedua atau Lima Dimensi lamanya pembinaan antara 1-2 tahun. Sedangkan masalah pembiayaan sepenuhnya menjadi tanggungan 
| Metode Terapi dan Rehabilitasi Korban Napza

orang tua anak bina, yang besarannya tergantung pada kemampuan orang tua masingmasing.

Berkaitan

dengan dalam

keterlibatannya penyalahgunaan napza, masingpermulaan yang berlai-lainan. Namun demikian pada dasarnya adalah bahwa sebagian besar keterlibatan mereka adalah karena lingkungan pergaulan. Usia mereka bervariasi antara 16 hingga 55 tahun. Pengalaman R-1 menuturkan bahwa keterlibatannya dalam penyalahgunaan napza, pada awalnya adalah karena dipaksa teman. Pada akhirnya menjadi kebiasaan dan ketergantungan pada saat batang usianya baru berumur 15 tahun. Kehadirannya di PP Suryalaya adalah dipaksa oleh orang tuanya untuk menjalani pembinaan. Begitu pula dengan pengalaman R-2, R-3, R-4, dan R-5 bervariasi menegaskan bahwa keterlibatannya karena teman pergaulan. Dikatakan dengan polos bahwa dirinya akan sembuh dari ketergantungannya apabila temantemannya sudah pada mati semua. Beragam pengalaman dan keterlibatan memerlukan perlakuan yang berbeda pula terutama dalam hal lamanya pembinaan dan penyadaran.

Metode penyadaran atau pembinaan korban penyalahgunaan napza merupakan satu paket kurikulum yang dilaksanakan secara ketat dan intensif dalam suatu feriode tertentu. Adapun metode yang diterapkan adalah melalui pendekatan Ilaahiyah yang terdiri dari mandi taubat, shalat fardlu dan sunah, dzikir jahar dan khofi, serta puasa.

\section{a. Mandi Taubat}

Mandi taubat merupakan hal yang penting dalam proses penyadaran korban penyalahgunaan napza. Dalam pelaksanaannya, mandi taubat dilaksanakan pada pukul 02.00 WIB sebelum melaksanakan shalat malam atau tahajud. Menurut keyakinan pembina pondok merupakan terapi untuk menghilangkan racun dari tubuh penderita. Sebab, air yang dingin menyebabkan saraf-saraf meregang dan aliran darah lebih lancar menuju ke otak. Kalau mabuk diumpamakan sebagai penyakit rohani, dengan izin Allah pasti dapat disembuhkan dengan mandi. Mandi adalah bagian dari bersuci yang dalam ilmu Fiqh dikenal dengan istilah Thaharah. Bersuci di sini mengandung pengertian bahwa anak bina diusahakan agar ia suci badan, pakaian, tempat tinggal, dan segala yang digunakan dalam menempuh hidupnya, termasuk suci kalbu, jiwa, dlomir, dan rasa. Atau sederhananya suci lahir dan suci batin. Sayang, sampai saat ini belum ada ahli yang menyelidiki hubungan kesembuhan penyakit rohani dengan mandi. Tampaknya untuk hal ini diperlukan penelitian khusus tentang hubungan mandi dengan terapi penyembuhan tersebut. 


\section{b. Shalat Fardlu dan Sunah}

Setelah mandi dilanjutkan dengan salat, baik salat wajib, salat sunah taubat, rawatib, qiyamullail, dan salat sunah lain yang dilakukan pada sepertiga malam (pukul 03.00). Setelah salat dilanjutkan dzikir. Shalat merupakan gerakan fisik dan mental dalam rangka berkomunikasi dengan Allah SWT. Shalat yang dilaksanakan dalam pembinaan atau penyadaran adalah sesuai dengan tuntutan dalam AlQur'an dan Hadist yakni shalat wajib dan shalat sunah yang jadwal pelaksanaannya disusun dalam kurikulum yang telah ditentukan.

\section{c. Djikir Jahar dan Khofi}

Djikir merupakan bagian dari ibadah yang diperintahkan oleh Allah SWT. Setelah mandi taubat dan dianggap mulai timbul kesadarannya, ia kemudian meneruskan proses selanjutnya dengan diarahkan agar mengenal, mengesankan, dan mencintai Allah SWT. Pengarahan itu dilakukan dengan merawat kalbunya melalui proses dzikir yang disebut talqin dzikir. Dasar teori dzikir adalah AlQur'an dan Hadist. Dasar teori AlQur'an yang berbunyi:...wa alazamahun kalimat al-takwa.. Yang dimaksud kalimat Al-taqwa adalah Laa ilaaha illallah, dengan syarat mengambil kalimat ini dari hati yang bersih bukan kalimat yang didengar dari orang awam. Dalam hal ini disyaratkan kalimat tersebut diajarkan oleh seorang mursyid yang silsilahnya bersambung hingga Rasulullah. Perlunya talqin dari seorang mursyid karena fungsi talkin ada dua yaitu: pertama, untuk memberikan pengatahuan formalitas yang bersifat lahiriyah tentang kalimat takwa bagi anak bina. Kedua, untuk memberikan pengetahuan yang hakiki yaitu untuk menghidupkan hati nurani anak bina. Memang pemberian ilmu yang hakiki tentang kalimat taqwa ini hanya mungkin dihidupkan oleh hati nurani yang hidup pula, sesuai dengan petunjuk $\mathrm{Al}^{\prime}$ Qur'an dalam Surat Muhammad (47:19).

Talqin djikir merupakan suatu proses awal seseorang akan mempelajari tasawuf atau Thareqat Qodiriyah Wa Naqsabandiyah. Dengan talkin djikir oleh Abah Anom terhadap korban penyalahgunaan napza diharapkan dapat membangunkan tingkat kesadarannya, sehingga timbul penyesalan dan mengetahui akan segala kesalahan atau dosa yang telah dilakukannya yang selama ini tidak disadarinya. Adapun djikir yang dilaksanakan dalam Thareqat Qodiriyah Naqsabandiyah ada dua macam yaitu djikir jahar dan djikir khofi. Djikir jahar yaitu mengucapkan kalimat tauhid yang terdiri dari pernyataan nafi (negasi) dan itsbat (menetapkan). Pernyataan nafi adalah laa ilaah dan pernyataan itsbat adalah illallaah. Jika dilakukan berkesinambungan, djikir ini dapat berfungsi menghilangkan syirik jali dan khofi mendatangkan sifat ikhlas, melepaskan kalbu dari segala yang menhalangi hubungannya dengan Allah, membersihkan jiwa dari segala sifat tercela, menghilangkan sifat-sifat kehewanan manusia, mendatangkan pengetahuan yang 
diperoleh dari Allah, mendatangkan pengetahuan tentang rahasia yang menampakkan keagungan Allah. Jikir jahar dapat berfungsi menghidupkan kembali kalbu anak bina atau siapapun yang mengamalkannya jika djikir itu diajarkan melalui proses dari seorang mursyid; dilakukan dalam keadaan suci (berwudlu); dilakukan dengan suara kuat; dan sesuai dengan petunjuk Rasul.

Sedangkan dzikir khofi dilakukan oleh kalbu (hati), dalam hal ini hati harus selalu ingat dan menyebut nama Allah. Dzikir khofi adalah metode untuk menanamkan dan membina komponen keimanan pertama dan utama. Al-hadist mengatakan: La yakum al-sa"at alawajh al-ardli man yaqul Allah. Di muka bumi ini tidak akan terjadi qiamat bagi orang yang mengucapkan Allah. Teknik dzikir khofi harus ditalqin oleh mursyid sebagaimana Rasul mentalqin sahabatnya Abu Bakar Al-Shidiq. Dengan demikian melalui djikir anak bina dialihkan dari kelezatan yang bersifat halusinasi kepada kelezatan yang bersifat hakiki, yakni "melihat" Allah dengan cermin di hatinya.

\section{d. Puasa}

Puasa merupakan terapi penunjang karena tidak semua diharuskan melalui kegiatan ini. Bagi mereka yang sudah baik dan sadar dianjurkan untuk melaksanakan puasa Senin dan Kamis, puasa tiga hari setiap bulan, kecuali puasa fardlu pada bulan
Ramadlan seluruh anak bina diharuskan untuk melaksanakannya.

Di samping kegiatankegiatan yang sifatnya religius tadi, juga untuk menghilangkan rasa jenuh para anak bina diberi waktu kegiatan untuk olah raga (seperti main bola, basket ball, volley ball, tenis meja, jogging, dan lain-lain), yang waktunya sore hari setelah selesai shalat Asar. Mereka juga diberi fasilitas televisi dan alat musik gitar untuk rileksasi yang dimaksudkan untuk meningkatkan kesehatan fisik, kebugaran, dan merangsang kembali timbulnya gairah hidup.

\section{G. Simpulan}

Metode penyadaran atau pembinaan yang dilakukan oleh PP Suryalaya melalui Pondok Inabah terhadap korban penyalahgunaan napza melalui seperangkat kurikulum yang dilaksanakan secara ketat dan intensif dalam suatu feriode tertentu. Adapun metode yang diterapkan adalah melalui pendekatan Ilaahiyah yang terdiri dari mandi taubat, shalat fardlu dan sunah, dzikir jahar dan khofi, serta puasa. Adapun materi rehabilitasi selain keempat komponen tersebut adalah melalui membaca Al-Qur'an, pengajian rutin mingguan dan bulanan, do'adoa, dan pembelajaran tentang keimpuan seperti Fiqh, Tauhid, Akhlak, Tasawuf, dan lain sebagainya.

Menurut penjelasan $\mathrm{KH}$ Zaenal Abidin Anwar, dzikir yang 
diucapkan dengan lisan membawa pengaruh pada yang mendengarkan. Ibarat orang mendengarkan musik dangdut, dengan tidak sadar tangan atau kaki bergerak-gerak mengikuti iramanya. Demikian juga dengan dzikir, kalimat tauhid, kalimat toyibah yang diucapkan dengan ritme teratur akan menyentuh nurani yang mendengarkan. Pada saatnya, mereka akan mengikuti lafal dzikir tersebut.

Selain tiga terapi religius tersebut (mandi, salat, dzikir) masih ada tambahan terapi, yakni puasa sunah. Biasanya, puasa Senin-Kamis dan ziarah, baik ke makam ulama atau tokoh masyarakat yang punya jasa besar bagi agama. Puasa sunah bertujuan agar penderita dapat mengendalikan diri, baik perilaku, tindakan, maupun ucapan. Kegiatan ziarah ke makam bertujuan mendoakan dan memohonkan ampun yang sudah meninggal dan mengenang jasa-jasanya agar mereka mampu meneladaninya. Setelah empat puluh hari mengikuti terapi regilius secara teratur diadakan evaluasi dengan tanya jawab oleh para pengasuh. Kalau menunjukkan hasil baik, baru dilakukan tahap rehabilitasi. Dalam tahapan ini mereka diperbolehkan bersosialisasi dengan teman-teman di luar Pondok Inabah.

Dalam pondok itu juga diadakan pemeriksaan kesehatan oleh dokter-dokter spesialis. Selain itu, juga ada pemanduan bakat untuk persiapan pendidikan keterampilan, sebagai bekal setelah mereka keluar. Tentunya tujuan umum dari penyelenggaraan program rehabilitasi tersebut adalah: terbentuknya ketahanan komunitas dan generasi muda terhadap penyalahgunaan dan peredaran gelap napza; terbentuknya perilaku mantan pecandu yang berakhlakul karimah. Sedangkan tujuan khususnya adalah dalam rangka meningkatkan derajat kesehatan pecandu baik jasmani maupun rohani; meningkatnya kesadaran pecandu untuk abstinen; meningkatkan rasa percaya diri pecandu untuk bersosialisasi; meningkatkan kesadaran pecandu untuk senantiasa berdzikir kepada Allah; dan menumbuhkan kesadaran pecandu beramar ma'ruf nahi mungkar.

\section{Daftar Pustaka}

Abidin, Zaenal A. 2006. Peranan Inabah Pondok Pesantren Suryalaya. Tasikmalaya: PP Suryalaya.

Krippendorff, Klaus. 1991. Content Analysis: Introduction Its Theory and Methodology", Alih Bahasa Farid Wajidi, Analisis Isi: Pengantar Teori dan Metodologi. Jakarta: Rajawali.

Miles, M.B. and Huberman, A.M. 1984. Qualitative Data Analysis: A Sourcebook of New Methods. Beverly Hills CA: Sage Publications.

Moleong, L.J. 1999. Metodologi Penelitian Kualitatif. Bandung: Remaja Rosdakarya. 
| Metode Terapi dan Rehabilitasi Korban Napza

Muhadjir, Noeng. 1996. Metodologi Penelitian Kualitatif. Yogyakarta: Rake Sarasin.

Patton, M.Q. 1980. Qualitative Evaluation Methods. Beverly Hills, CA.: Sage Publication.

Spradley, J.P. 1980. Participant Observation. New York, N.Y.: holt, Rinehart, and Winston.

Sunardjo, Unang. 1995. Sejarah Pondok Pesantran Suryalaya. Tasikmalaya: Yayasan Serba Bakti PP Suryalaya.

Sutopo, H.B. 1995. Kritik Seni Holistik Sebagai Model Pendekatan Penelitian Kualitatif. Surakarta: UNS Press.
Sutopo, H.B. 1996. Metodologi Penelitian Kualitatif. Surakarta: Jurusan Seni Rupa Fakultas Sastra UNS.

Syah, Anang. 2000. Inabah. Tasikmalaya: Pndok Pesantren Suryalaya.

Waluyo, H.J. 2000. "Hermeneutik Sebagai Pusat Pendekatan Kualitatif", dalam Historika, No.11. Surakarta: PPS UNJ KPK UNS.

Yin, R.K. 1987. Case Study Research: Design and Methods. Beverly Hills, CA: Sage Publication.

Sumber lisan, Zaenal Abidin Azwar, Anang Syah, R-1, R-2, R-3, R-4, R-5, wawancara, minggu, 26 Nopember 2006. 
| Puji Lestari

DIMENSIA, Volume 6, No. 1, Maret 2012 | 16 